\title{
SOTAQUES E SINTAXES: ACENTUANDO O FALAR CABOCLO NAS RELIGIÕES AFRO-BRASILEIRAS
}

\author{
Mauricio dos Santos (D)
}

Universidade Federal da Integração Latino-Americana

Thiago de Azevedo Pinheiro Hoshino (D) $\nabla$

Universidade Federal do Paraná Rede Nacional de Religiões Afro-Brasileiras e Saúde (Renafro)

O texto que ela cantava, língua de branco não era. Tão nasal, tão desconhecido que imaginei fala de índio. Mas era latim... de tapuio. ${ }^{1}$

Canoa de arariba, remo de araribá, a canoa de caboclo tem boca e sabe falar. ${ }^{2}$

\begin{abstract}
\ Cantar, para os caboclos”, nos conta Mãe Marina Tunirê, sacerdotisa do Ilê Axé Ogun Funmilayó, em Foz do Iguaçu, “é uma forma de conversar, de falar”. Assim, neste trabalho, pretendemos nos aproximar da linguagem de algumas entidades presentes nas religiões afro-brasileiras, a partir de trabalho de campo com o candomblé e a umbanda. ${ }^{3}$ Focalizamos nossa observação na fala dos caboclos. De acordo com o antropólogo Jocélio Teles, o culto aos caboclos perpassa o
\end{abstract}

1 Mário de Andrade, Compêndio de história da música, $2^{\mathrm{a}}$ ed., São Paulo: L. G. Miranda, 1933, p. 178.

2 Luiz Rufino, Histórias e saberes de jongueiros, Rio de Janeiro: Multifoco, 2014.

3 "Entidade” é uma categoria nativa que indica seres não-vivos que são, porém, entendidos como espíritos ou “encantados”, capazes de se manifestar via transe de possessão. 
candomblé de várias nações: de Jeje, de Ketu e de Angola. ${ }^{4}$ Ainda, integra o batuque, o tambor de mina, o xangô, a jurema, o catimbó, o xambá, o omolokô, a quimbanda e muitas outras tradições religiosas de matriz africana. O caboclo é uma das entidades mais notórias - se não a mais da umbanda convencionalmente representada em paralelo ou confluência com o próprio mito nacional brasileiro de três raças fundadoras, como fruto do encontro afro-ameríndio e europeu. ${ }^{5}$

A incontestada "brasilidade" do caboclo e sua vinculação com a capacidade e a necessidade de inovação dentro da tradição, ou melhor, de acionar modalidades particulares de tradução cultural, faz dele um ícone linguístico privilegiado, um signo condensador. Segundo Lody, ele é "antepassado da nova terra, da terra brasileira, por isso merecedor de rituais novos, não semelhantes àqueles dedicados aos ancestrais africanos, porém determinando uma nova categoria mitológica que foi absorvida pelos candomblés”. ${ }^{6}$ Em algumas leituras, “o caboclo é o índio que viveu num tempo mítico anterior à chegada do homem branco, mas um índio que conheceu a religião católica e se afeiçoou a Jesus, a Maria e a outros santos;

4 Jocélio Teles dos Santos, O dono da terra: o caboclo nos candomblés da Bahia, Salvador: Sarah Letras, 1995. "Nação” é uma categoria nativa que opera como signo diacrítico (e marcador geopolítico da diáspora negra) entre tradições oriundas de distintas localidades na Âfrica.

5 É explícita a relação dos caboclos com a terra. Mãe Marina assim a enuncia: "isso se passou há muito tempo na época da escravização dos negros no Brasil. E que foram os bantos africanos da Angola e do Congo quem despertaram o culto aos caboclos na nova terra. Pois na África devotavam uma entidade, muito amada, consagrada à terra e aos antepassados. Essa entidade era considerada por eles/as como o Nkisi (divindade de alguns povos bantos) dono da terra. Os bantos acreditavam que essa entidade iria permanecer junto com eles na nova terra. Porém ao cruzarem a calunga grande - o oceano - e ao serem escravizados, o Nkisi dono da terra olhando isso tudo acontecer, entristeceu-se. E ele já não mais cedia às homenagens que lhe eram prestadas. Não acolhia mais as oferendas que lhe eram feitas. E nem respondia mais no jogo de búzios (prática divinatória das religiões de matriz africana). Nkisi dono da terra não aceitava, de forma alguma, ser cultuado na nova terra, no Brasil. E com isso os bantos igualmente entristeceram-se. Eles achavam que o dono da terra lhes havia dado às costas. E com isso magoaram-se. Muito tempo depois. Decidiram encontrar um outro antepassado para compor a falta do Nkisi que não os acompanhou na nova terra. E assim fizeram. Nomearam o índio, o caboclo brasileiro, como dono da terra e antepassado do Brasil”.

6 Raul Giovanni da Motta Lody, Samba de caboclo, Rio de Janeiro: Arte-Funarte, 1977, p. 19. 
um índio que viveu e morreu no Brasil”. ${ }^{7}$ Caboclo é signo de multiplicidade: "Das princesas turcas aos beberrões maltrapilhos, do rei da França aos bugres guerreiros, dos vulgos matutos das campinas e sertões, às mais diferentes expressões e seres viventes. Na canjira dos encantados todos podem baixar sob o estatuto ontológico de caboclo”. ${ }^{8}$ Invariavelmente, contudo, o mundo dos caboclos, “o mundo celeste não está distante, nem superior, e o crente pode conversar diretamente com os deuses e aproveitar da sua beneficência”. ${ }^{9}$ Caboclo está entre nós, fala e responde.

Essa proximidade é determinante na performance dos caboclos durante o transe dos adeptos da religião: gostam de estar próximos dos filhos de santo e por dos frequentadores do terreiro; são muito animados, podem cantar e dançar por longo tempo; às vezes brincam e convidam as pessoas também para as brincadeiras; costumam curar e receitar preparos como remédios; são valentes, altruístas e apreciam muito beber e fumar, mas, sobretudo, gostam de conversar. Alguns mais sisudos, outros mais cordiais, eles são, de qualquer maneira, faladores. Enquanto os orixás e inquices, ${ }^{10}$ em suas festas, dançam, raramente falam publicamente e interagem apenas com algumas autoridades religiosas, os caboclos se comunicam com todos e, não raro, agem como mensageiros. Essas mensagens podem surgir também recitadas ou cantadas, em público ou em momentos reservados. Representados como oriundos das matas ("caboclo de pena”), dos campos (“caboclo boiadeiro”) ou mesmo das águas (caso de alguns encantados, assim como dos chamados "marinheiros” ou “marujos”), os caboclos são sempre versados no verso.

7 Reginaldo Prandi. Encantaria brasileira: o livro dos mestres, caboclos e encantados, Rio de Janeiro: Pallas, 2001, p. 20.

8 Luiz Antonio Simas e Luiz Rufino, Fogo no mato: a ciência encantada das macumbas, Rio de Janeiro: Mórula, 2018, p. 99.

9 Edson Carneiro, Candomblés da Bahia, $5^{\mathrm{a}}$ ed., Rio de Janeiro: Civilização Brasileira, 1977, p. 31.

10 Divindades do candomblé associados a ancestrais ilustres, forças da natureza e domínios da vida social. Quanto aos voduns, divindades da nação Jeje e do tambor de mina, é sabido que podem falar mais livremente, inclusive em português. 
Segundo a etnolinguista Yeda Pessoa de Castro, o português dos caboclos é um português "rudimentar". Seu vocabulário é quase o mesmo da língua de santo (repertório que mescla iorubá, línguas bantas, assim como outras línguas africanas, e o português), com a especificidade de alguns termos indígenas, sobretudo do tronco tupi-guarani. Durante os transes, é comum que murmurem ou gritem onomatopeias, além de outros sons remissivos a animais ou fenômenos naturais, como assobios. ${ }^{11}$ Alguns religiosos creem que se comunicam assim quando mobilizam a língua dos animais, das plantas, das águas, numa inegável referência aos trânsitos e práticas xamânicas.

A despeito da extensa literatura antropológica no campo das religiões afro-brasileiras, a figura do caboclo ainda é pouco teorizada. Suas relações com o falar nessas (e dessas) tradições merece maior atenção. Nos tópicos seguintes, buscaremos enveredar por esse "abc" seguindo a "pisada" dos caboclos (assim eles mesmos diriam) como metalinguagem religiosa afro-brasileira. A própria "língua de santo" é, a seu modo, um falar "caboclo".

Os dados etnográficos apresentados advêm de pesquisa de campo realizada entre 2016 e 2018 em diversos terreiros de umbanda e de candomblé, principalmente o Ilê Axé Oju Ogun Funmilayó e o Abassá de Xangô e Caboclo Sultão, terreiros de tradição Ketu e Angola - o primeiro situado em Foz do Iguaçu e o segundo em São Paulo. Parte dos registros coletados integra uma pesquisa mais ampla sobre a chamada "língua de santo", linguagem religiosa falada não somente pelo candomblé, mas também por outras religiões afro-brasileiras. A importância da oralidade nessas tradições está expressa nas próprias cantigas: "Canoa de arariba, remo de araribá, a canoa de caboclo tem boca e sabe falar".

11 Yeda Pessoa de Castro, Falares africanos na Bahia: um vocabulário afro-brasileiro, Rio de Janeiro: Academia Brasileira de Letras, 2001, p. 91. 


\section{Do que falam os caboclos? Sotaque de santo}

Os caboclos podem conversar por muitas formas. Dentre os seus registros linguísticos mais notórios está o “sotaque”. Diferente da acepção corrente como variação linguística, o "sotaque” enquanto categoria nativa nomeia uma situação em que alguém - religioso ou caboclo em possessão de seu corpo - desafia outro religioso ou entidade a responder ao que foi cantado ou falado. Esse desafio em forma de bravata estabelece um diálogo, uma alternância entre cantadores. As respostas devem ser feitas em forma de improviso ou com cantigas já conhecidas. Em qualquer dos modelos, a leitura do contexto é central. Alguns consideram o sotaque uma forma de disputa, uma briga em si. Para outros, o sotaque é mais um conflito encenado como alegoria para poder versejar. Assim, a dinâmica do sotaque mais se aproxima da embolada, do coco de embolada, coco de improviso ou ainda do repente, práticas culturais poéticas e populares muito comuns no Nordeste do Brasil.

Fato é que o sotaque é um drama social: não se "lança” sotaque sozinho, pois um outro está sempre pressuposto e engajado. Sempre há uma possibilidade latente de que a interlocução se converta em intervenção e nem sempre os envolvidos num sotaque reagem bem ou fazem as pazes. Por isso mesmo, muitas vezes ele é evitado ou ignorado.

Dificilmente o sotaque pretende ofender ou insultar. Em algumas situações, tem caráter pedagógico, buscando alertar quem esteja demasiado em evidência ou extrapolando sua posição hierárquica; aqui o domínio linguístico e poético é ostentado nele. Isso quer dizer que o conhecimento dos caboclos e dos religiosos é demonstrado pela vastidão de seu repertório de palavras, recitações, cantigas e respostas: da língua de santo. Um verso é tanto mais apreciado ou exitoso quanto mais consiga mobilizar contexto e tradição conjuntamente. Com os sotaques, que são talvez a forma mais complexa de se conversar no culto dos caboclos, encantados e religiosos demonstram que detêm 
tanta potência na oralidade, descrita pelo povo-de-santo como o "axé da fala”, que podem mesmo inventar novas cantigas ou construir sobre bases melódicas e rítmicas preexistentes outras variações poéticas. Bons "sotaqueiros" pretendem deixar os demais sem palavras ou sem respostas possíveis para o que entoaram. É assim que um sotaque acaba: com silêncio. De acordo com Silva, “o conhecimento nestas religiões enfatiza sobretudo os contextos performáticos da fala: quem fala, para quem se fala, o que, quando e onde se fala”. ${ }^{12}$

Pudemos identificar ao menos duas modalidades formais de “sotaques”. Uma possui uma frase como refrão, repetida entre todos os participantes: muitas pessoas podem participar e não importa quem desafiou quem, pois todos desafiam todos, ainda que possam surgir enredos mais pessoais, por vezes desdobramentos de antigas antipatias e tensões sociais entre os caboclos ou entre seus filhos. Estão entre esses sotaques de chamada, que podem servir também para incitar que entidades “peguem” (possuam) seus filhos:

Quebra a cabaça espalha a semente,

Chama os caboclo pra brincar com a gente.

Moro na roça Iá, Iá,

Nunca morei na cidade,

Compro o jornal da manhã,

Pra saber das novidades.

Sabiá cantou

Na ladeira miudinho

Sabiá cantou

Na ladeira miúda

12 Vagner Gonçalves da Silva, "Segredos do escrever e o escrever dos segredos. Reflexões sobre a escrita etnográfica nas religiões afro-brasileiras” in Aulo Barretti (org.), Dos Yorubá ao Candomblé Kétu (São Paulo: Edusp, 2010), p. 274. 
O outro tipo de sotaque não tem refrão. Ele é evocado no momento adequado na forma de improviso e, na maioria das vezes, consiste num desafio de um único religioso ou caboclo para outro. Às vezes, pode ser muito delongado, o que reforça o conhecimento daquele que o cantou. Como, por exemplo, os versos abaixo usados como resposta de um "mais velho" ao sotaque lançado por um "mais novo":

Sou eu, cantador de harmonia,

Conheço a força do gado,

$O$ gado é que manda na lei,

A lei é que manda no gado,

Casei com Maria Preta,

No ano de vinte e quatro,

Sujei meu uniforme branco,

Perdi meu pé de sapato,

Se você quer me bater,

Ô menino,

Sou eu quem lhe bato.

Que vaqueiro é esse

Que entrou no meu roçado

Tocou fogo na fazenda

Queimou o capim do gado

O gado não era meu

Era um pasto alugado

Ô que vaqueiro malvado

Conforme explica Pai Ubaldino Bomfim (Tata Luango), sacerdote do Abassá de Xangô e Caboclo Sultão, em São Paulo, esse tipo de textualidade admite variações segundo a ocasião. A disseminada sequência abaixo traz uma última estrofe como deferência das entidades ou de um religioso a outro, em reconhecimento ao seu pertencimento à tradição: 
Sete meses de nascido

Minha mãe me abandonou

Me jogou na folha seca

Pai Oxóssi me apanhou

Quando eu vinha lá de cima

Vindo pra morrer de sede

Botei minha boca n’água

Só de Deus me alembrei

Botei minha boca n’água

Só de Deus me alembrei

Tua mãe era de jêje

O teu pai de jêje é

Tua mãe prepara a pemba

O teu pai de jêje é

Tu foi feito na macumba

Se criou no candomblé

O conflito, conquanto evitado, faz parte do aprendizado no candomblé. O caráter pedagógico desses enfrentamentos emerge, por exemplo, nos versos abaixo, que se referem às fofocas ou a pessoas maledicentes (supostamente comentando sobre o versador ou sobre um terceiro), no momento da cerimônia. Vale lembrar que a fofoca é tema corrente nos terreiros, recebendo o nome de "indaka de afofô" ou de "mavula”, o que indica que os sotaques podem ter finalidade de admoestação por quebras da etiqueta social ou ritual:

Na praia da Amaralina,

Vi dois camarão sentado,

Falando da vida alheia,

Êta camarão danado. 
Caboclo tu olha tu

Caboclo tu olha lá

A língua que fala muito

O corpo é que vai pagar

Em cenas como essa, comuns e mais ou menos estruturadas dentro do universo religioso, a resposta de um dos “camarões” pode se dar, como observamos, na forma de outro sotaque, agregando até novas camadas a cantigas de conhecimento compartilhado (no caso, um sotaque de chamada que se converte em sotaque de desafio endereçado):

Quebra a cabaça espalha a semente,

Joga na língua que fala da gente.

Você diz que sabe muito

Lagartixa sabe mais

Ela sobe na parede

Coisa que você não faz

A partir deste ponto, uma tréplica poderia encetar todo um “drama ritual”, ${ }^{13}$ inclusive perturbando o curso da festa ou da liturgia ou tendo desdobramentos mágicos. Um verso ou sotaque lançado com intenção maldosa pode ser, ao mesmo tempo, um meio de enfeitiçar pela palavra. No mundo do verso, todo cuidado é pouco, porque o sotaque é “uma palavra-arma”, na cirúrgica expressão cunhada por Siqueira. ${ }^{14}$ De fato, ambos, sotaque e feitiçaria, "envolvem uma dimensão menos harmoniosa da relação entre seres espirituais e humanos, fazem parte do que se chama, na religião, de a 'linguagem do candomblé’”, o seu “enredo”. Mas o sotaque evidencia algo

13 Yvonne Maggie, Guerra de orixá, Rio de Janeiro: Jorge Zahar, 2001.

14 Paula Siqueira, "O sotaque dos santos: movimentos de captura e composição no candomblé do interior da Bahia”, Tese (Doutorado em Antropologia Social), Universidade Federal do Rio de Janeiro, Rio de Janeiro, 2012, p. 5. 
que na consideração do termo feitiçaria a princípio poderia não transparecer. Nele, “as dimensões estéticas estão evidentes". ${ }^{15}$

Nesse sentido, Pai Ubaldino nos relatou um embate por ele presenciado entre o Caboclo Vigia de uma mãe-de-santo e um visitante de uma casa de axé:

Foi num terreiro no Alto do Cansanção, em Jequié (BA). Este senhor não gostava de candomblé e não gostava que sua esposa desse santo. [...] Então ele foi buscá-la à força numa sessão de caboclo. Chegando lá quem estava na terra era o Caboclo Vigia da mãe-de-santo, de quem ele zombou e deu as costas. ${ }^{16}$

Segundo conta o sacerdote, o caboclo então "zuelou”:

Tu olhou pra mim

Tu olhou e sorriu

Te deu dor de cabeça

Tu rodou e caiu

Depois da cantiga, segue Pai Ubaldino: “Quando o homem ia saindo do terreiro, antes de colocar o pé pra fora, deu um troço nele, ele caiu. O caboclo foi que tirou dele, que teve de levantar ele. Tempos depois, ele virou filho de santo dessa casa”. A conclusão do pai de santo é peremptória: “Não se deve bulir com caboclo!”. E arremata, fazendo menção ao seu próprio caboclo: "Existe até uma cantiga de Seu Sultão que diz isso né?”:

Sultão gemeu

No pé da serra gemeu

Sultão gemeu

15 Siqueira, “O sotaque dos santos”, p. 7.

16 Entrevista cedida aos autores da pesquisa. 

Ô pra que bole
Ô pra que bole com ele,
Pra que bole?

A decisão sobre até onde seguir com um sotaque pode ser determinante e, amiúde, sacerdotes intervêm para interromper o ciclo de respostas e reestabelecer a cordialidade, o que pode ocorrer ao iniciarem uma nova sequência de cantigas. ${ }^{17}$

Calar-se, destarte, ou silenciar a outrem podem ser modulações do falar caboclo. Muitos dos cânticos, por vezes denominados "chulas” ou "zuelas” em congo, samba, cabula e barravento metalinguisticamente abordam a fala dos caboclos e também dos viventes:

Falei, falei,

Falei no abrir da boca,

Falei no abrir da boca,

Vou falar no abrir da boca,

Falei, falei.

Dona da casa me dê licença

Pra eu falar com a senhora,

Falar com a língua ligeira,

Passei na roseira e tirei uma rosa [...]

O sotaque não é um verso pronto e sim uma construção contextual e coletiva que se produz em interação. Qualquer cantiga, em última

17 Eis uma cena deste tipo: em um toque de caboclo, na casa do Babalorixá Roberto de Oxalá, um caboclo de outro terreiro cantou: “Toma lá vaqueiro / Toma jaleco de couro / Toma jaleco de couro / Na porteira do curral”. Na mesma hora o caboclo do pai de santo se demonstrou bravo e perguntou: “esse sotaque é pra mim?” dando risada começou a cantar: "Então vem tomar / Então vem tomar / Na porteira do curral”. A peleja foi interrompida por uma Ekédi (religiosa iniciada que não entra em estado de transe), pedindo que parassem e os silenciaram enquanto o primeiro "sotaqueiro" se distanciou. 
instância, pode operar como sotaque na hora própria e com "endereço certo”. Essa leitura de tempo-espaço e do ajuste e pertinência dos gestos rituais a eles faz parte do aprendizado silencioso - porque mimético e

participativo - das religiões afro-brasileiras. Por isso, o sotaque não é brincadeira e recomenda-se aos mais novos abster-se de usá-lo: mesmo sem sabê-lo, é possível lançar um sotaque caso alguém entenda que as palavras lhe foram direcionadas. E aí, até que o mal-entendido se desfaça, muita água pode rolar. A conflituosidade do sotaque é um caso extremo que remete ao risco que toda fala porta: o de que as nossas palavras se voltem contra nós.

\section{Cavalo de santo}

Os tambores, “engomas” ou “couros” nessas cantigas são personagens frequentes e representam a própria fala ou a capacidade de comunicação entre os mundos e pessoas:

Em ritmo congo

Lá de cima me mandaram um aviso,

Lá de cima me mandaram um aviso,

Mandaram perguntar se esse couro não batia,

Eu disse bate sim senhor,

Na fé de deus e de meu Pai Angoro.

(noutras versões, “na fé de deus e do Cristo Redentor”).

No ritmo barravento

Quando Oyá falou,

E o couro gemeu,

Os caboclos dessa aldeia,

Todos se tremeu. 
Mata bruta, mata fria,

O couro cantava,

E caboclo caía [...]

Fala couro,

Fala ligeiro,

Fala couro,

E responde boiadeiro.

É interessante que a maioria dessas cantigas, tanto as que tratam da fala, quanto as que falam sobre os couros, também são cantos de chamada que, por vezes, podem funcionar como sotaques ou desafios aos presentes. Contudo essas cantigas são usadas principalmente para convidar ou para invocar os caboclos a participarem dos toques ou os religiosos a dançarem com os caboclos. Como se pode observar, ao longo da cerimônia, as "chamadas” de caboclo podem crescer em intensidade, passando quase a reprimendas:

Em ritmo cabula

Vem sambar mais eu

Vem sambar mais eu, mano meu

Em ritmo congo

Só quero ver se eu vou ficar sozinha

Só quero ver se eu vou ficar sozinha

No meio de tanto rei

No meio de tanta rainha

Em ritmo barravento

É sangue é sangue

É sangue de ariri

Quem tem sangue de caboclo

Tá na hora de cair 
Pode ser tida como ofensiva a atitude de recusar um convite dos caboclos para integrar a roda, sobretudo do caboclo de um mais velho, visto que o "axé” circula na interação. A literatura antropológica tem descrições densas de cenas deste tipo. ${ }^{18}$ Não é qualquer pessoa, contudo, que está autorizado a tirar, puxar ou botar as chulas mais agressivas de chamada, até porque o tipo de toque utilizado na evocação pode determinar o tipo de caboclo a chegar em terra ou seu estado de chegada (mais “calmos” ou "bravos”).

Enfim, o couro do filho de santo responde e obedece ao couro do tambor. A ideia ensina que tanto os religiosos quanto os orixás, voduns, nkises e outras entidades ("catiços") dançam, falam, recitam ou cantam porque foram devidamente "esquentados", isto é, foram encorajados a responder aos tambores. Os próprios tambores devem ser "cuidados” periodicamente para que possam dinamizar as demais existências:

O sol, o lua, o sol, o lua,

Clareia o mundo pra vocês passar,

Esquente aldeia pra gente chegar.

Tava me chamando,

Me chamando ê,

Tava me chamando,

Eu vim obedecer.

Portanto, os caboclos e pessoas cantam, dançam, falam, recitam, ou entram em transe porque são esquentados. O termo "esquentados" relaciona-se também aos padrões rítmicos codificados para as cerimônias e empregados em momentos distintos. Toques mais acelerados e agitados são considerados "quentes", enquanto toques mais lentos são tidos por “frios”. Por exemplo, o alujá, que é um toque consagrado a Xangô, é quente. O ijexá - tocado para Oxum, Ologunedé e Oxalá - e o igbin - consagrado

18 Siqueira, “O sotaque dos santos”, p. 5. 
ao orixá Oxalá - são considerados frios. Os toques seguem a "natureza” mais fria ou mais quente das próprias divindades (em última instância, todos os elementos da natureza, como as folhas, são efetivamente classificados como "quentes” ou "frios”, do que derivam seus protocolos).

É corrente afirmar que, numa cerimônia religiosa de candomblé, os tocadores (alabês da nação Ketu, huntós da nação Jeje ou xicarangomas da nação Angola) devem ter o zelo de mesclar toques quentes e frios, ou seja, devem "temperar” a cerimônia. Uma roda de santo quente demais pode queimar, isto é, prejudicar, tanto os filhos de santo como as divindades e a casa. Como o frio também “queima”, o contrário pode ser igualmente prejudicial.

"Queimar” ou “queimar-se”, seguindo esta lógica, é também o risco do sotaque, mesmo quando proposto como brincadeira para “esquentar” o samba. Porém, alguns orixás ligados ao fogo - como Xangô e Oyá - com ele brincam sem se queimar. Há vários “atos” dessa natureza nas cerimônias de candomblé. Embora, na umbanda, os caboclos possam apresentar-se como filiados à "linha” ou "falange” de qualquer orixá, a relação entre essas “entendidas” e o orixá Oxóssi - também conhecido como Odé - é patente:

Ele atirou,

Ele atirou e ninguém viu,

Só Oxóssi é quem sabe,

Onde a flecha caiu.

Em algumas versões dessa cantiga, Oxóssi é substituído por caboclo e não é incomum que os termos “caboclo” e "orixá” se fundam num orixá-caboclo: o caçador. Essa figuração aparece em muitos terreiros de umbanda, mas também nos de candomblé, não raro indicando Oxóssi como o patrono, chefe ou "cacique" dos caboclos: ${ }^{19}$

19 Na música “Oxóssi”, de Roque Ferreira: “Na lua Oxóssi é Odé / Odé, Odé / Rei de Keto / Caboclo das matas / Odé [...] A jurema é a árvore sagrada / Okê, Arô, Oxóssi, Okê, Okê”. 
Se ele é caboclo ele é flecheiro,

Ele é Oxóssi ele é caçador.

A composição caboclo-orixá dá margem a ciclos de sotaques em nome de Oxóssi:

Ô meu pai Oxóssi

Venha me valer

Que meus inimigos

Quer é combater

Não combate não

Que Jesus não quer

Minha Santa Bárbara

É rainha da Guiné

Ô meu pai Oxóssi

Dai-me força e proteção

Aqui é casa de santo

Não é brincadeira não

Longe de qualquer interpretação normativa que compreenda esse processo como uma "fusão”, ou pior, uma “confusão”, interessa-nos enfatizar que a sintaxe cabocla das religiões afro-brasileiras permite cruzar - mas não necessariamente sincretizar - ambos os signos: caboclo e orixá. Se a sintaxe pode ser pensada no plano das relações de concordância, subordinação e ordem entre elementos, uma sintaxe cabocla é aquela que permite conectar, (des)montar e (re)construir diferentes modos simbióticos.

Inspirados na noção de "eventos simbióticos” de Stengers e seus desdobramentos como espaço de convivência entre práticas e seres diferentes, Rabelo e Aragão bem sugerem que "as relações entre orixás e caboclos - entidades de ethos (e, para muitos, também de procedência) bem distintos - constituem um campo privilegiado para entendermos o modo (ou 
pelo menos um modo) como o candomblé acolhe, integra e conecta práticas diferentes”. ${ }^{20}$ As possibilidades simbióticas do candomblé, para os autores, se apoiariam "em uma ética que ensina a manejar a distância de modo a evitar tanto sua dissolução completa (na proximidade excessiva que nivela), quanto sua exacerbação (no afastamento excessivo que congela as diferenças e, no limite, produz o desinteresse)". ${ }^{21}$ Sotaque, sintaxe e simbiose.

Os modos de conexão e permeabilidade (ou simbiose) dessa sintaxe cabocla são experienciados no corpo e narrados a partir dele. Como nos comentou Mãe Marina Tunirê:

Oxóssi às vezes é compreendido como um caboclo. Porque eles são muito parecidos. Eles moram no mato e caçam. Morreram e voltaram da morte. Se enfeitam com as penas e com o couro dos animais. Falam as línguas indígenas, das plantas e dos animais. Sofreram por amor e muitas vezes morreram por isso..$^{22}$

Oxóssi teria morrido e retornado conhecendo os segredos da morte. Tanto Oxóssi quanto os caboclos são tidos por alguns religiosos como encantados, entidades que não acreditam ou que não passaram pela morte. A não destruição pela morte permite que suas histórias sejam contadas e inscritas em seus próprios corpos e, por conseguinte, nos corpos e seus filhos, quando deles se apossam.

Tomando, ao lado de Simas e Rufino, como noção a metáfora do encantamento, podemos afirmar que as línguas africanas também não morreram, encantaram-se. ${ }^{23} \mathrm{Na}$ contramão da retórica da “perda”, elas continuaram a vicejar, versejar, e a se enredar em diferentes modos da (des)reterritorialização simbólica e semântica. Passaram a ser como

20 Miriam Cristina Marcilio Rabelo e Ricardo Aragão, “Caboclos e orixás nos terreiros: modos de conexão e possibilidades de simbiose”, Religião e Sociedade, v. 38, n. 1, (2018), p. 85.

21 Rabelo e Aragão, “Caboclos e orixás nos terreiros”, pp. 105-106.

22 Entrevista cedida aos autores da pesquisa.

23 Simas e Rufino, Fogo no mato. 
espíritos, que ao mesmo tempo estão ali, mas às vezes também não estão, se diz dos encantados, mas, com igual sabedoria, diremos o mesmo dos seus dizeres.

Este talvez seja um dos "segredos” do falar caboclo: diversos idiomas de matriz africana se recompuseram, no Brasil, na língua de santo, artefato afro-diaspórico. ${ }^{24} \mathrm{Na}$ pura potência de fala que é Exu, dono da comunicação (Alaroyê), a boca que tudo come (Enugbarijó) é a que tudo reelabora e devolve. Também a boca que tudo canta e encanta. ${ }^{25}$ A língua portuguesa, encantada, passa a ser uma espécie de “cavalo” da língua de santo.

“Cavalo de santo” não é uma categoria desconhecida da antropologia das religiões de matriz africana ou afro-brasileiras:

são religiões de possessão, isto é, por ocasião das cerimônias, certos indivíduos, em estado de transe, são "possuídos” pelas entidades espirituais, as quais, segundo a terminologia nativa, "se ocupam” da

24 Mas não só. Também idiomas indígenas, mesmo que miticamente ou etnocentricamente, também podem eventualmente ser recompostos na expressão de caboclo. Mãe Marina nos contou que a primeira mãe de santo de Foz do Iguaçu era conhecida como Vô Benedita de Nanã. E que ela tinha um caboclo que conversava em guarani, língua indígena e paraguaia. A mesma coisa também nos contou o pai de santo Júnior de Oxóssi, que disse que o caboclo de Vô Benedita era um caboclo de pena conhecido como Aimoré. Contaram esse caboclo atendia seus clientes paraguaios/as falando em guarani e com tamanha destreza que às vezes os/as próprios/as paraguaios/as não entendiam o que ele estava falando. Pois esse caboclo falava um guarani arcaico, assim como os caboclos no Brasil falam um português arcaico. Ainda, afirmaram que os caboclos que falam guarani são bastante comuns nos terreiros de umbanda e candomblé no Paraguai. Como sugere uma das epígrafes deste texto.

25 "É nessa trama, articulada à noção de Enugbarijó, que se baixa também o conceito de orixá como potência. Essa noção parte do pressuposto de que a potência do signo reivindicado pode incorporar outros signos e por consequência ressignificá-los. Assim, no dia 23 de abril, abrem-se as porteiras para cultuar-se tanto o santo católico, quanto o orixá negro-africano, como também o santo incorporado no orixá. Essa terceira opção conota as expressões que se manifestam fazendo bricolagem de diferentes referências e por consequência inventam outros sentidos. [...] A noção de orixá como potência indica que a energia, nesse caso, referente ao signo Ogum pode vir a ser encantada nas mais diferentes formas práticas e agentes o corpo do devoto, o assentamento do orixá, o trilho da linha férrea, as espadas de São Jorge [...]” Simas e Rufino, Fogo no mato, pp. 70-71. 
pessoa, em cujo corpo podem cavalgar. Assim, o corpo do iniciado se torna o "cavalo de santo". ${ }^{26}$

Também na Nigéria se fala que o elegun ou iniciado está "montado" pela divindade e o termo nomina uma das mais notórias obras de Zora Hurston, Tell my Horse, expressão que os loa haitianos comumente utilizam (racontez cheval me: “diga ao meu cavalo" isto ou aquilo). ${ }^{27}$

A partir dessa referência, tomamos novamente uma noção êmica para defender que o idioma português também pode ser pensado como um “cavalo da língua de santo”. Nessa imagem, a língua de santo frui e flui da estrutura da língua portuguesa para se presentificar, usando, por exemplo, os verbos, adjetivos, subjetivos, artigos, numerais, preposições entre outras categorias de palavras como seu veículo, porém submetendo-as a estruturas, sentidos e usos imprevistos ou gramaticalmente “incorretos”. A língua portuguesa estaria para o cavalo de santo assim como a língua de santo estaria para o ente que cavalga o corpo do filho de santo. A língua portuguesa seria o corpo - atualidade - por meio do qual a língua de santo - potencialidade pode se manifestar em transes linguísticos. Trans(e)duções.

Interessante reparar que tanto os religiosos quanto os orixás, voduns, inquices e outras entidades usam do que acreditamos se tratar de uma modalidade de diglossia, no sentido proposto por Charles A. Ferguson em 1959. A noção de diglossia nos serve para nomear e refletir sobre a situação linguística de um grupo em que dois ou mais ou registros linguísticos funcionalmente diferenciados coexistem, sendo que o uso de um ou de outro depende da situação comunicativa. ${ }^{28} \mathrm{Ou}$ seja, a diglossia nos ajuda a pensar que tanto o português quanto a língua de santo (em alguns casos, como na tríplice fronteira Brasil-Argentina-Paraguai, também o espanhol e o guarani) convivem e são usados de forma semi-independente,

26 Ari Pedro Oro apud Mauro Dillmann Tavares e Fernando Ripe, “Cavalo de santo: religiões afro-gaúchas”, Horizontes Antropológicos, v. 18, n. 37 (2012), pp. 411-414.

27 Zora Neale Hurston, Tell My Horse: Voodoo and Life in Haiti and Jamaica, Philadeplhia: J.P. Lippincott Company, 1938.

28 Charles Ferguson, “Diglossia”, Word, v. 15, n. 2 (1959), pp. 325-340. 
modulados a partir da situação comunicativa, porém mantendo certas relações de influência e interseção. Assim como o português é ou pode ser — o cavalo da língua de santo, o espanhol e o guarani também podem sê-lo e, aliás, já o são, segundo indicam os dados de etnografias dessa região. Qualquer idioma pode ser enredado no santo ou virado nele, tornando-se sua língua. Se para muitos religiosos os caboclos são eguns, espíritos de pessoas mortas que se manifestam, seria a língua de santo o fantasma (fantôme) que habita ou que se incorpora à língua portuguesa? ${ }^{29}$

A rentabilidade teórica da noção de “cavalo de santo" para pensar a fala dos caboclos e a linguagem do candomblé, como de outras tradições afro-brasileiras, pode ser amplificada em contraste com a fala dos egunguns. Sobre este culto (lessé Egun), com fortes raízes na Ilha de Itaparica, Bahia, vale notar que é dedicado, precipuamente, aos ancestrais. Egungun (também babá, babá egun ou egun) é um termo que designa os espíritos de ancestrais ilustres, pessoas mortas que, periodicamente, adquirem o direito de retornar à terra de maneira visível e que seguem tendo agência. Materializam-se em meio a grandes cerimônias e festas, com vestes muito ricas e coloridas, portando símbolos característicos de sua hierarquia e do orixá a que pertencem(ram). Os babá egun se destacam por estarem cobertos com uma roupa específica enfeitada com búzios, espelhos e contas, chamada de opá na Bahia. ${ }^{30}$ Braga, ao referir-se ao Ilê Agboulá, famoso templo do culto de babá egun, tombado pelo Instituto

29 Utilizamos o termo "fantasma” aqui em acepção escancaradamente lacaniana, conscientes e contentes com o fato de que “o termo lacaniano 'fantasma' é, a bem dizer, um neologismo da psicanálise brasileira. Em francês há duas formas de se traduzir 'fantasia': ou bem se opta pelo termo antigo e em desuso fantaisie, ou bem se traduz, no melhor da língua, por fantasme. Porém, se quisermos dizer 'fantasma' o Gasparzinho, por exemplo - em francês, não há dúvidas: a palavra a ser usada será fantôme, bastante alheia ao vocabulário psicanalítico. Portanto, quando, ao lermos Lacan, encontramos a palavra "fantasma" no lugar de fantasia, trata-se de um erro de tradução. Um 'erro’ que vingou porque, como veremos, ele permite incluir uma discriminação entre as formações do inconsciente que, não estando presente no texto freudiano, é correlativa da invenção por Lacan do objeto a”. Maria Cristina Poli, “Construção da fantasia, constituição do fantasma” in Carmen Backes (org.), A clínica psicanalítica na contemporaneidade (Porto Alegre: Editora da UFRGS, 2007), p. 43.

30 Juana Elbein dos Santos, Os nagô e a morte, Petrópolis: Vozes, 1976. 
do Patrimônio Histórico e Artístico Nacional (IPHAN), conta que lá há um Egun Caboclo e o descreve: "No terreiro de Babá Aboulá, é um Egun Caboclo - Babá Iaô - que, quase sempre, encerra a festa. Nessa ocasião todos/as, já do lado de fora do barracão, cantam em homenagem a um dos mais festejados Eguns daquele terreiro”. ${ }^{31}$ Mesmo num culto considerado de grande ortodoxia pelo povo de santo, está presente o caboclo como ancestral dono da terra, desta terra em que o axé africano vingou.

Os eguguns, afirma a literatura, falam de maneira particular: com uma voz gutural inumana, rouca, ou às vezes aguda, metálica, estridente e característica, relacionada com a voz do macaco mítico, chamado ijimerê na Nigéria. ${ }^{32}$ Os ojés, os sacerdotes do culto de egungun, não entram em transe, mas compreendem os dizeres dos ancestrais, interpretam suas mensagens e as traduzem: "são os ojés, que levam os pedidos da comunidade e trazem as vontades e conselhos dos baba eguns, pois eles são os únicos que entendem o que os babas falam”. ${ }^{33}$ Ainda, segundo Barretti Filho, assim como os caboclos fazem no candomblé, babá egun durante suas falas estará orientando, abençoando, punindo e, se necessário, fazendo o papel de um verdadeiro pai, presente entre seus descendentes para aconselhá-los e protegê-los. ${ }^{34}$

Os ojés interpretam as falas dos Baba Eguns, traduzindo-as. Função similar é exercida por pessoas que auxiliam nas consultas dos caboclos, normalmente chamados de cambonos. Todavia, ao contrário dos caboclos, que se manifestam por meio do transe de possessão e se utilizam do corpo dos "cavalos” para se comunicar, os egunguns se manifestam sem “cavalo”. Ainda, há regulações específicas da fala, Eguns agbas são aqueles que já tiveram os seus ritos completos, que duram sete anos, e que por isso podem usar suas vozes para conversar e cantar com os vivos,

31 Júlio Santana Braga, Ancestralidade afro-brasileira: o culto de babá egum, Salvador: CEAO, 1992, p. 47.

32 Aulo Barretti Filho (org.), Dos Yorubá ao Candomblé Kétu, São Paulo, Edusp, 2010.

33 Fábio Macêdo Velame, “O Lessayn: o coração de um terreiro de Egun”, Fundação Palmares, p. 14 ש.

34 Barretti Filho, Dos Yorubá ao Candomblé Kétu. 
ao contrário de Eguns mais jovens, que não podem ou conseguem falar e cantar. A ideia de que "santos velhos” estejam autorizados a falar em contraste com "santos novos” também permeia o culto Lessé Orisá e foi repetida por diversos de nossos interlocutores. ${ }^{35}$

Ver e falar com os ancestrais é o objetivo maior do culto de babá egun. ${ }^{36}$ Dar voz e vez aos caboclos e divindades também é um dos objetivos primordiais das religiões afro-brasileiras, nas quais a materialidade do "cavalo" se faz fundamental. A isso se chama dar "passagem”. Ao santo ou catiço se dá passagem no corpo para que venha em terra. Também essa passagem pode ser a chave (interpretativa, ao menos) para o segredo (inter-dito) da língua de santo: sua ausente presença. Como bem sentenciou Mãe Marina: “Às vezes apenas o que resta são as falas, ditas e não ditas, pelos vivos e pelos mortos”.

\section{Pode o caboclo falar?}

O tipo de codificação apresentada nas interações comunicacionais como o sotaque pode ser, em parte, interpretado como um caso-limite dos sentidos de "risco" e “prevenção” que povoam o universo do candomblé também em figuras como a feitiçaria e nos recorda que, como o capitalismo, o racismo e a colonialidade, somos sujeitos da precariedade. ${ }^{37}$ Por outro lado, são igualmente uma extensão da lógica do segredo (awô), ou do inter-dito nas religiões afro-brasileiras.

35 Barretti Filho, Dos Yorubá ao Candomblé Kétu.

36 Santos, Os nagô e a morte.

37 "O conceito de prevenção caminha junto com a ideia de vulnerabilidade. Stengers e Pignarre definiram o capitalismo como um sistema feiticeiro, que usa a descrença de suas vítimas como arma. Todos corremos o risco de nos tornarmos subordinados ao sistema capitalista, mesmo os que se julgam protegidos (por seu próprio pensamento crítico, por exemplo). Somos todos presas em potencial, somos todos vulneráveis. E, principalmente, os que foram capturados (e tiveram a sua alma roubada) não têm consciência disso." Clara Flaksman, "Culpa e cuidado no candomblé baiano”, Revista do Instituto de Estudos Brasileiros, n. 69 (2018), p. 318. 
Mesmo quando caboclos, orixás, voduns, inquices e egunguns se permitem falar a língua dos viventes, essa fala não é autoevidente ou prosaica e precisa ser decifrada, "traduzida”. Ela interpela o seu próprio destinatário. A fala é parábola ou charada que, como o sotaque, desafia o interlocutor. Nelas, texto e contexto se enredam, incorporam um no outro, a língua de santo faz o português de seu cavalo: pretoguês, na irretocável formulação de Lélia González. ${ }^{38}$ Nesse limiar, tradução parece um conceito insuficiente para o que se faz nos terreiros. Algo como uma trans(e)dução será possível?

Parafraseando o famoso texto de Spivak, nos perguntamos: pode o caboclo falar? ${ }^{39}$ "Sotaque", como registro conflituoso de interação social, e "cavalo", como materialidade potente porque performativa, podem fornecer pistas do caminho por onde "caboclo", metonímia também das trocas e trânsitos culturais, faz passagem. Se o caboclo fala enviesado, é porque a incorporação das línguas de santo no português tensiona e é tensionada pela lógica subalternizante do racismo epistêmico: para falar de algo tão presente, mas tão silente, tão estruturante, mas tão dissimulado, há que se falar por charadas ou alegorias, pois é o segredo que desvela o segredo. Será este o segredo dos caboclos? Vagner Gonçalves da Silva, ao comentar uma nota de Pierre Verger, recorda: "o que é segredo em uma casa não é segredo em outra. O que é segredo numa nação não é segredo em outra. O que é segredo no Brasil, não é segredo na África”. ${ }^{40} \mathrm{O}$ que é secreto e o que é sagrado, como a língua de santo, são

38 "É certo que a presença negra na região caribenha (aqui entendida não só como a América Insular, mas incluindo a costa atlântica da América Central e o norte da América do Sul) modificou o espanhol, o inglês e o francês falados na região [...] Ou seja, aquilo que chamo de 'pretoguês' e que nada mais é do que marca de africanização do português falado no Brasil (nunca esquecendo que o colonizador chamava os escravos africanos de 'pretos' e de 'crioulos' os nascidos no Brasil), é facilmente constatável sobretudo no espanhol da região caribenha”. Lélia Gonzalez, “A categoria político-cultural de amefricanidade”, Tempo Brasileiro, n. 92/93 (1988), pp. 69-82.

39 Gayatri Chakravorty Spivak, Pode o subalterno falar?, Belo Horizonte: Editora UFMG, 2010.

40 Vagner Gonçalves da Silva, “Segredos do escrever e o escrever dos segredos”. 
modos da conversação e se o antropólogo tem lá sua magia, a academia tem também seus sotaques. Uma sintaxe simbiótica requer achar o tom em que a fala dos pesquisadores responde à fala dos caboclos. E então poderá, ou poderão, talvez, algo (con)dizer.

Recebido em 1 mar. 2020

Aprovado em 5 out. 2020

doi: 10.9771/aa.v0i62.35680 
Os caboclos são espíritos e encantados afro-ameríndios que podem se manifestar por muitas formas nas religiões de matriz africana. Em comum têm a capacidade (nem sempre compartilhada por outras divindades, como os orixás) de falar. Mais do que uma capacidade, trata-se de uma habilidade codificada por meio da qual exercem sua agência sobre o mundo e sobre seus adeptos. Dentre os registros linguísticos mais notórios dos caboclos está o "sotaque", categoria nativa que nomeia uma situação de desafio em forma de bravata que estabelece um diálogo, uma alternância entre (en)cantadores. Considerado como disputa, mais do que briga, o sotaque sempre dramatiza um conflito como alegoria e abre a possibilidade de encenar, de inovar, de versejar e de construir contextualmente sobre o texto da tradição. Por sua vez, essa enunciação depende sempre da materialidade de um "cavalo" que a vocalize, dando "passagem" ao sujeito oculto pelo racismo estrutural, epistêmico e cotidiano. O presente artigo toma as noções êmicas de "sotaque" e de "cavalo-de-santo" como conceitos rentáveis para projetar as tensões e atravessamentos da linguagem do candomblé, em cuja dinâmica o português é enredado com usos, sentidos e acentos e assentos afro-atlânticos, fazendo dele "pretoguês”, uma língua em modo de simbiose ou, como os autores defendem, uma "sintaxe cabocla".

\section{Religiões afro-brasileiras | Caboclo | Sotaque | Língua de santo | Pretoguês}

\section{Accent and Syntax: the Voice of Caboclos in Afro-Brazilian Religions}

Caboclos are Afro-Amerindian spirits that manifest in various ways in the African matrix religions of Brazil. They have the ability to speak (not always shared by other divinities of the cult, like Orixás). More than an ability, speaking in this case constitutes a codified mode of agency over the world, the people, and specially their believers. Among the most well-known Caboclo linguistic registers is the sotaque (literally "accent", but in this context more akin to "sneer"). Sotaque is a native category referring to situations in which one entity challenges another, in a swaggering way, resulting in a competitive dialogue between them. Considered a dispute, not a fight, a sotaque generally dramatizes conflicts in an allegorical way, opening up possibilities for performing, innovating, versifying, providing contexts for building on traditional texts. In turn, such enunciation depends on the materiality of the cavalo ("horse") that verbalizes it, "clearing the path" for subjects hidden by structural, epistemic and quotidian racism. This paper draws from emic notions of sotaque and cavalo de santo as fruitful concepts for projecting the tensions that are part of the language of Candomble, in which the use of Portuguese is coupled with Afro-Atlantic usages, meanings, and accents, in what could be termed "pretoguês": a language of symbiosis, or, as the authors suggest, a "caboclo syntax".

Afro-brazilian Religions | Caboclo | Sotaque | Língua de santo | Pretoguês 